Appeared as: J.T. Smith, A.V. Kudelsky, I.N. Ryabov, R.H. Hadderingh (2000) Radiocaesium concentration factors of Chernobyl-contaminated fish: a study of the influence of potassium and "blind" testing of a previously developed model. Journal of Environmental Radioactivity, 48 (3), 359-369.

\title{
Radiocaesium concentration factors of Chernobyl-contaminated fish: a study of the influence of potassium, and "blind" testing of a previously developed model.
}

James T. Smith, Institute of Freshwater Ecology, East Stoke, Wareham, Dorset, BH20 6BB, UK.

Anatoly V. Kudelsky, Institute of Geological Sciences, Zhodinskaya Str. 7, Minsk 220141, Belarus.

Igor N. Ryabov, A.N. Severtsov Institute of Ecology and Evolution of the Russian Academy of Sciences, Leninsky Prospekt 33, Moscow, RU-117071, Russia.

Rolf H. Hadderingh, KEMA Power Generation, P.O. Box 9035, 6800 ET Arnhem, Netherlands.

\begin{abstract}
The radiocaesium concentration factors $(\mathrm{CF})$ of different fish species in 10 lakes in Russia, Belarus and Ukraine were measured between 6 and 11 years after the Chernobyl accident. Clear inverse relations were observed between fish CF and lakewater $\mathrm{K}^{+}$concentration. Perch (a predatory species) had CF's which were two times higher than non-predatory fish. No differences in CF's were observed between different species of non-predatory fish. An empirical model for the prediction of radiocaesium CF's in fish (Rowan and Rasmussen, 1994) was blind-tested against our measurements. The model predictions, based on measurements of $\mathrm{K}^{+}$and suspended solids concentrations in the lakewater, were in good agreement with measured values. Our observations, however, implied a stronger effect of $\mathrm{K}^{+}$on $\mathrm{CF}$ than that used in the Rowan and Rasmussen (1994) model. Further improvements in models could also be made by accounting for the effect of fish size on $\mathrm{CF}$.
\end{abstract}




\section{Introduction}

Studies on the contamination of aquatic systems following the Chernobyl accident have shown that, in general, radiocaesium activity concentrations in water declined relatively rapidly (Vakulovsky et al., 1994; Smith et al., 1997). Bioaccumulation of radiocaesium in fish, however, resulted in activity concentrations (both in Western Europe and in the former Soviet Union) which were in many cases significantly above the maximum permissible level for consumption. In many lakes in Russia and Belarus these problems have continued to the present day and evidence suggests that they may continue for the forseeable future.

The level of radioactive contamination of aquatic biota is commonly defined in terms of a concentration factor $(\mathrm{CF})$ where

$$
\mathrm{CF}=\frac{\text { Activity concentration per kg of fish (wet wt.) }}{\text { Activity concentration per litre of water }} \quad 1 \mathrm{~kg}^{-1}
$$

As a result of accumulation of radiocaesium with CF's in the range $10^{2}-10^{4} 1 \mathrm{~kg}^{-1}$ (Foulquier, 1979), fish have remained relatively highly contaminated despite relatively low radiocaesium activity concentrations in water. In the Chernobyl Cooling Pond ${ }^{137} \mathrm{Cs}$ activity concentrations in carp (Cyprinus carpio), silver bream (Blicca bjoerkna), perch (Perca fluviatilis) and pike (Esox lucius) were of order $100 \mathrm{kBq} \mathrm{kg}^{-1}$ wet weight (w.w.) in 1986, declining to a few tens of kBq kg${ }^{-1}$ in 1990 (Kryshev and Ryabov, 1990; Kryshev, 1994). In lakes in the Bryansk region of Russia, approximately 300 km away from the Chernobyl NPP, activity concentrations in a number of fish species varied 
within the range $0.215-18.9 \mathrm{kBq} \cdot \mathrm{kg}^{-1}$ w.w. during the period 1990-92 (Fleishman et al., 1994). In Norwegian lakes, Brittain and co-workers (Brittain et al., 1991) found that activity concentrations in brown trout (Salmo trutta) were in the range $2-13 \mathrm{kBq} \mathrm{kg}^{-1}$ shortly after the accident, declining to $0.5-5 \mathrm{kBq} \mathrm{kg}^{-1}$ in 1989 . In Alpine lakes in Germany, levels in pike were around $8 \mathrm{kBq} \mathrm{kg}^{-1}$ shortly after the Chernobyl accident (Lindner et al., 1990). Concentrations of radiocaesium in fish declined relatively rapidly between 1986 and 1989 with an ecological half-life of around 2-3 years (Brittain et al., 1991; Kryshev, 1994), but there is evidence to suggest (Fleishman et al., 1994; Smith et $a l .$, 1998) that between 1990 and 1992 levels stabilised, so that rates of decline in activity concentrations may decrease to close to the physical decay half-life of ${ }^{137} \mathrm{Cs}, 30.2$ years.

The processes which determine the accumulation of radiocaesium in fish are complex, and lead to wide differences in contamination levels according to fish type, size and feeding patterns. The most important pathway of radiocaesium into fish is via intake of food, and the high concentration factors observed are a result of accumulation of radiocaesium through the food chain. In general, predatory fish such as pike and perch show higher concentration factors than herbivorous species. The "size effect" of radiocaesium accumulation in fish most commonly results in an increasing contamination (per unit weight of fish) with increasing fish size (Elliott et al., 1992; Hadderingh et al., 1997).

Studies on weapons-test derived ${ }^{137} \mathrm{Cs}$ found that the concentration factor of radiocaesium in fish was inversely proportional to the potassium content of the surrounding water (Fleishman, 1973; Blaylock, 1982; Rowan and Rasmussen, 1994). This relation has not, to our knowledge, previously been tested for lakes in the regions contaminated by the Chernobyl accident. The purpose of our study was to test the inverse relation between radiocaesium $\mathrm{CF}$ in fish and $\mathrm{K}^{+}$concentration in lakewaters for 
lakes in the regions surrounding Chernobyl. A model developed by Rowan and Rasmussen (1994) using data from weapons-testing and routine power station discharges is blind-tested against our measurements of Chernobyl-contaminated fish.

\section{Methods}

Samples of fish were taken from 10 lakes located in Russia, Belarus and Ukraine (see Fig. 1 for lake locations and Table 1 for a general description of the lakes). Sampling from the Chernobyl Cooling Pond, the Kiev Reservoir and Lake Kazhanovskoe was carried out during the period 1992-1994. Samples from the 7 other lakes were taken during 1996 and 1997.

Fish were caught using gill nets and divided by species, sex and size groups. The operculum was removed from perch and scale samples taken from other fish species for age determination. Length and total and somatic (ie without organs) weights were determined. Fish were prepared for (-counting by removing the head, tail and organs, dried at $105^{\circ} \mathrm{C}$ and ground. Dry weights were determined. For very small fish, the whole fish was measured (ie including head, tail and organs), and individuals were combined to give sufficient sample for counting. Fish radiocaesium activity concentrations are presented as activity concentration per $\mathrm{kg}$ of wet weight (w.w.).

Water samples were collected in $25 \mathrm{~L}$ containers, filtered through $1: \mathrm{m}$ filter papers, then concentrated on a caesium specific ion-exchange resin prior to (-counting of the filtrate. Sub-samples were taken for measurement of the water chemistry, including potassium. Where samples from more than one sampling visit were 
available (between 1 and 4 visits were made to each lake), mean values of ${ }^{137} \mathrm{Cs}$ determinations and water chemistry were calculated.

Concentration factor $(\mathrm{CF})$ values for different fish species in each of the 10 lakes were calculated. Because of the "size effect" of radiocaesium accumulation in fish (Elliott et al., 1992; Hadderingh et al., 1997), which commonly results in an increasing contamination (per unit weight of fish) with increasing fish size, we have restricted the analysis to fish samples within a given size range: of length $10-20 \mathrm{~cm}$. Samples of roach (Rutilus rutilus) in the Kiev reservoir and goldfish (Carassius auratus gibelio) in Lake Kazhanovskoe had mean lengths above this range $(22 \mathrm{~cm}$ and $32 \mathrm{~cm}$ respectively), but these species showed no evidence of changes in CF with size, and so these data were also included in the analysis.

Errors

Errors in ${ }^{137} \mathrm{Cs}$ determination of fish samples by (-counting were $<10 \%$. Error in the measurement of ${ }^{137} \mathrm{Cs}$ in water samples was $10-15 \%$. Variation of activity concentrations between different samples of the same fish population is somewhat more difficult to quantify, since variation has a number of causes, amongst which are different feeding patterns of individual or groups of fish and seasonal effects. We have estimated the variation in samples of roach taken from Lake Svyatoe, Chechersk (Lake 7). A large number of fish (186) were caught during two sampling periods (May, October, 1997). The fish were divided into 15 bulk samples of between 3 and 19 fish, and the bulk samples counted for ${ }^{137}$ Cs. Mean activity concentrations of fish sampled during the two periods showed good agreeement, being $99.6 \forall$ S.E. 7.1 in 
May and $106 \forall$ S.E. 3.0 in October. The standard deviation of the activity concentrations of the 15 bulked samples was $12 \%$.

\section{Results and Discussion}

As shown in Fig. 2, an inverse relationship is observed between the ${ }^{137} \mathrm{Cs}$ concentration factor in fish and the lakewater potassium concentration. Measurements of CF's and water and fish data for each of the lakes are presented in Table 2 . The slightly higher CF's in perch (approximately 2 times higher than in the other species) are commonly observed and can be attributed to different feeding patterns or greater biological half life of ${ }^{137} \mathrm{Cs}$ in perch than in the other species (Hadderingh et al., 1997). There is no significant difference in CF's between the different non-predatory species.

An equation of the form:

$$
C F=\frac{A}{\left[K^{+}\right]^{B}}
$$

was fitted to the observed data using SAS statistical software package (SAS Institute Inc.) where $\mathrm{CF}$ is measured in $1 \mathrm{~kg}^{-1}$ and $\left[\mathrm{K}^{+}\right]$is in $\mathrm{mg}^{-1}$. The $\mathrm{CF}$ data showed a variation of approximately 2 orders of magnitude, so fits were carried out on log transformed values by linear regression, using:

$$
\log [C F]=A-B \log \left[K^{+}\right]
$$


Parameter values were back-transformed for presentation of results. The fitted value of B for perch was $1.1 \forall 0.41$ and for roach the value was $0.93 \forall 0.29$, where errors show $95 \%$ confidence limits in parameter estimates. Since neither value of B is significantly different to 1.0 , we also carried out fits assuming a (theoretically expected) value of $\mathrm{B}=1.0$, giving the following empirical relations:

$$
C F(\text { perch })=\frac{4880(\text { Range }: 1780-7590)}{\left[K^{+}\right]}
$$

and

$$
C F(\text { roach })=\frac{2390(\text { Range }: 1740-3280)}{\left[K^{+}\right]}
$$

where figures in brackets give the range ( $95 \%$ confidence) in parameter estimates. Fig. 2 shows the fits of eqs. (4) and (5) to the measurements for perch and roach, and also shows the good agreement of the relationship for roach (Eq. (5)) with the measurements of other non-predatory species.

The inverse relation between radiocaesium $\mathrm{CF}$ and potassium concentration are in agreement with previous studies carried out following atmospheric nuclear weapons testing (Fleishman, 1973; Blaylock, 1982). We have, for the first time, shown that this relation also applies to fish contaminated by the Chernobyl accident. In a large study of bioaccumulation of radiocaesium in fish contaminated by nuclear weapons test fallout, and by routine discharges from nuclear sites, Rowan and Rasmussen (1994) developed empirical relationships for the CF of freshwater fish. These relationships were not applied to fish contaminated by Chernobyl, since, at the time, equilibration of the fish-water system could not be assumed (Rowan and 
Rasmussen, 1994). The CF's measured in the present study, conducted from 6-11 years after the Chernobyl accident, represent equilibrium $\mathrm{CF}$ values since the processes of accumulation and release of radiocaesium in fish (in the size group of small fish we have selected) had reached equilibrium before the beginning of our study.

We have used our data to carry out a "blind" test of the empirical relationships developed by Rowan and Rasmussen (1994). We have used their model for equilibrated systems, including what were considered to be only the most robust predictors of CF (termed, by Rowan and Rasmussen (1994) the bioaccumulation factor, or BAF). The model requires as input parameters only the potassium concentration and suspended solid concentration of the lakewater. The equation given by Rowan and Rasmussen (1994) (their Equation 5) is:

$$
\log [\mathrm{CF}]=3.320-0.718 \log \left[\mathrm{K}^{+}\right]+0.292[\text { trophic level }]-0.233 \log [s]
$$

where $\left[\mathrm{K}^{+}\right]$is the potassium concentration in $\mathrm{mg} \mathrm{l}^{-1}, s$ is the suspended sediment concentration in $\mathrm{mg}^{-1}$ and [trophic level] takes the value of 0 for non-predatory fish and 1 for predatory fish. Note that we have converted Eq. 6 to use $\mathrm{mg}^{-1}$ as units for $\left[\mathrm{K}^{+}\right]$rather than : $\mathrm{M}^{-1}$ as used by Rowan and Rasmussen (1994).

We have "blind" tested this empirical model using our data from the Chernobyl-contaminated lakes. Fig. 3 shows plots of CF values predicted using the model of Rowan and Rasmussen (1994) against our measured CF values. The model makes good predictions, with most estimates being within a factor of 2 or better of the measured values (Fig. 3). The difference in CF between predatory and non-predatory 
fish is also confirmed by our data. Eq. 6 predicts CF values which are 1.96 times higher in predatory fish than non-predatory. This is in good agreement with our empirical relationships which give $\mathrm{CF}$ values which are 2.04 times higher for perch (Eq. 4) than for non-predatory species (Eq. 5).

Our study has highlighted some errors in the model predictions. These stem, partly, from the relation of $\mathrm{CF}$ with $\left[\mathrm{K}^{+}\right]$used in the Rowan and Rasmussen (1994) model. The coefficient of the inverse logarithmic relation is 0.718 in Eq. (6), whereas we have observed values closer to 1 (1.1 for perch and 0.93 for roach and other nonpredatory species). In addition, for perch, we observe some evidence of a size effect, even within the restricted size interval we have chosen. Regression of $\left(\mathrm{CFH}\left[\mathrm{K}^{+}\right]\right)$vs. wet weight for perch shows a weak, but significant $\left(R^{2}=0.46, p<0.05\right)$ positive relation, implying that some of the variance in the $\mathrm{CF}$ versus $\left[\mathrm{K}^{+}\right]$relations is attributable to fish size. No size effect was observed for roach in the size range we have studied. For perch (and, potentially, other predatory fish) of larger sizes than those we have studied, the model of Rowan and Rasmussen (1994), and the empirical relations we have developed (Eqs. $5 \& 6$ ) are likely to significantly underestimate concentration factors.

\section{Conclusions.}

We have shown that radiocaesium Concentration Factors $(\mathrm{CF})$ in fish in lakes situated in the Chernobyl contaminated regions of Russia, Belarus and Ukraine are inversely proportional to the potassium concentration of the lakewater. Perch (a predatory species) had CF's which were two times higher than non-predatory fish. 
Remarkably, no difference in CF's were observed between different species of nonpredatory fish. An empirical relationship for the prediction of ${ }^{137} \mathrm{Cs}$ CF's in fish (Rowan and Rasmussen, 1994), developed from studies of weapons test fallout, and routine power station discharges, was blind-tested against our measurements of fish contaminated by Chernobyl. The model (Rowan and Rasmussen 1994) gave good predictions, with most estimates being within a factor of 2 or better of the measured values. We have, however, observed a stronger inverse relation of CF with potassium than used in the Rowan and Rasmussen (1994) model. Models could be further improved by accounting for the effect of fish size on radiocaesium accumulation. 


\section{Acknowledgements}

The authors would like to thank Natasha Belova, Nikolai Gemba, Svyetlana Ovsiannikova, Vasily Pashkevitch, Alexander Petrovich and Alexander Petrikov for their contribution to this work. The work was supported by the CEC Inco-Copernicus programme, and by the British Natural Environment Research Council. 


\section{References.}

Blaylock, B.G. (1982) Radionuclide data bases available for bioaccumulation factors for freshwater biota. Nuclear Safety 23, 427-438.

Brittain, J.E., Storruste, A. and Larsen, E. (1991) Radiocaesium in Brown Trout (Salmo trutta) from a subalpine lake ecosystem after the Chernobyl reactor accident. Journal of Environmental Radioactivity 14, 181-191.

Elliott, J.M., Hilton, J., Rigg, E., Tullett, P.A., Swift, D.J. and Leonard, D.R.P. (1992) Sources of variation in post-Chernobyl radiocaesium in fish from two Cumbrian lakes (North-West England). Journal of Applied Ecology 29, 108-119.

Fleishman, D.G. (1973) Radioecology of marine plants and animals. In Radioecology, eds. V.M. Klechkovskii, G.G. Polikarpov, R.M. Aleksakhin, pp 347-370. John Wiley \& Sons, New York.

Fleishman, D.G., Nikiforov, V.A., Saulus, A.A. and Komov, V.T. (1994) ${ }^{137}$ Cs in fish of some lakes and rivers of the Bryansk region and North-West Russia in 1990-1992. Journal of Environmental Radioactivity 24, 145-158.

Foulquier, L. (1979) Étude bibliographique sur la capacité et les modalités de la fixation du radiocésium par les poissons. CEA-BIB-231 (2), (1979), pp. 360, CEA, Cadarache. Hadderingh, R.H., van Aerssen, G.H.F.M, Ryabov, I.N., Koulikov, A.O. and Belova, N. (1997) Contamination of fish with ${ }^{137} \mathrm{Cs}$ in Kiev Reservoir and old river bed of Pripyat near Chernobyl. In: Freshwater and estuarine radioecology eds. Desmet, G., Blust, R., Comans, R.N.J., Fernandez, J., Hilton, J. and de Bettencourt, A., pp. 339-351, Elsevier, Amsterdam.

Kryshev, I.I. (1994) Radioactive contamination of aquatic ecosystems following the Chernobyl accident. Journal of Environmental Radioactivity 27, 207-219. 
Kryshev, I.I. and Ryabov, I.N. (1990) About the efficiency of trophic levels in the accumulation of Cs-137 in fish of the Chernobyl NPP cooling pond. In: Biological and radioecological aspects of the consequences of the Chernobyl NPP accident, eds. I.N. Ryabov and I.A. Ryabtsev, USSR Academy of Sciences, Moscow.

Lindner, G., Becker, M., Eckmann, R., Petersen-Seyboldt, D., Jahn, S., Pfeiffer, W., Geissler, A., Stroh, B., Kissling, S., Wilhelm, C. and Zibold, G. (1990) Cesium-137 contamination of fish from two prealpine lakes. In: Biological and Radioecological Aspects of the Consequences of the Chernobyl Accident, eds. I.N. Ryabov and I.A. Ryabtsev, USSR Academy of Sciences, Moscow.

Rowan, D.J. and Rasmussen, J.B. (1994) Bioaccumulation of radiocaesium by fish: the influence of physicochemical factors and trophic structure. Canadian Journal of Fisheries and Aquatic Sciences 51, 2388-2410.

Smith, J.T., Leonard, D.R.P., Hilton, J. and Appleby P.G. (1997) Towards a generalised model for the primary and secondary contamination of lakes by Chernobyl - derived radiocaesium. Health Physics 72, 880-892.

Smith, J.T., Kudelsky, A.V., Rjabov, I.N., Hadderingh, R.H., van der Perk, M. and Voitsekhovitch, O.V. (1998, submitted) Chernobyl radionuclides $\left({ }^{131} \mathrm{I},{ }^{90} \mathrm{Sr},{ }^{137} \mathrm{Cs}\right)$ in surface waters of Belarus, Russia and Ukraine: an overview and model-based analysis. Verhandlungen Internationale Vereinigung Limnologie, submitted. Vakulovsky, S.M., Nikitin, A.I., Chumichev, V.B., Katrich, I. Yu., Voitsekhovitch, O.A., Medinets, V.I., Pisarev, V.V., Bovkum, L.A. and Khersonsky, E.S. (1994) Caesium-137 and Strontium-90 contamination of water bodies in the areas affected by releases from the Chernobyl Nuclear Power Plant accident: an overview. Journal of Environmental Radioactivity 23, 103-122. 


\section{List of Figures}

Figure 1. Map of the study sites. Lakes are numbered as in Table 1.

Figure 2. Plots of fish-water concentration factor against potassium concentration $\left[\mathrm{K}^{+}\right]$in 10 lakes in Belarus, Russia and Ukraine. Solid lines show the relations given in the text: Eq. 4 for perch (Perca fluviatilis) and Eq. 5 for roach (Rutilus rutilus) and other non-predatory species (rudd, Scardinius erythrophthalmus; ruffe, Gymnocephalus cernuus; gudgeon, Gobio gobio; bream, Abramis brama; goldfish, Carassius auratus gibelio).

Figure 3. 'Blind' test of the model of Rowan and Rasmussen (1994), shown here as Eq. 6, against our measurements of the fish-water concentration factor. Solid lines show 1:1 correspondence of predictions and measurements. Dotted lines show a factor of 2 error in model predictions. 
Table 1. General description of the study lakes.

\begin{tabular}{|c|c|c|c|c|c|c|c|}
\hline Site no. & Lake & $\begin{array}{c}\text { Water } \\
\text { surface area, } \\
\mathrm{km}^{2}\end{array}$ & $\begin{array}{l}\text { Depth (max), } \\
\mathrm{m}\end{array}$ & $\begin{array}{l}\text { Water volume, } \\
\mathrm{m}^{3}\end{array}$ & $\begin{array}{l}\text { Watershed } \\
\text { area, } \\
\mathrm{km}^{2}\end{array}$ & $\begin{array}{c}\text { Distance from the } \\
\text { ChNPP, } \\
\text { km }\end{array}$ & $\begin{array}{l}{ }^{137} \mathrm{Cs} \text { contamination } \\
\text { density in watershed* } \\
\mathrm{kBq} \mathrm{\textrm {m } ^ { - 2 }}\end{array}$ \\
\hline 1. & Tyumenskoye & 0.085 & 4.5 & 226720 & 2.712 & 232 & 482.8 \\
\hline 3. & Svyatoye, Kostyukovichy & 0.25 & 5.1 & 717950 & 1.02 & 225 & 1368.1 \\
\hline 6. & Kolpino & 0.21 & 2.61 & 393230 & 5.0 & 172 & 257.5 \\
\hline 7. & Svyatoye, Chechersk & 0.069 & 7.0 & 186250 & 0.67 & 170 & 515.04 \\
\hline 8. & Stoyacheye & 0.46 & 17.0 & 1991750 & 3.11 & 167 & 225.3 \\
\hline 15. & Kiev Reservoir & 922 & 14.5 & $3.7 \times 10^{9}$ & $2.4 \times 10^{5}$ & 60 & Very varied \\
\hline 16. & Cooling Pond & 22 & 18 & $15 \times 10^{7}$ & - & $1 \mathrm{~km}$ & - \\
\hline
\end{tabular}

* as of 01.01.1997 
Table 2. Water and fish data.

\begin{tabular}{|c|c|c|c|c|c|c|c|c|}
\hline No. & Lake & $\mathrm{K}^{+}(\mathrm{mg} / \mathrm{l})$ & $\mathrm{s}(\mathrm{mg} / \mathrm{l})$ & \multicolumn{2}{|c|}{$\begin{array}{l}{ }^{137} \mathrm{Cs} \mathrm{in} \mathrm{fish} \\
\text { (Bq kg }{ }^{-1} \text { w.w.) }\end{array}$} & $\begin{array}{c}{ }^{137} \mathrm{Cs} \text { in water } \\
\left(\mathrm{Bq}^{-1}\right)\end{array}$ & \multicolumn{2}{|c|}{$\begin{array}{c}\mathrm{CF} \\
\left(1 \mathrm{~kg}^{-1}\right)\end{array}$} \\
\hline 1. & Tyumenskoye & 1.1 & 1.4 & $\begin{array}{c}5006 \\
3200\end{array}$ & $\begin{array}{r}\text { (perch) } \\
\text { (rudd) }\end{array}$ & 1.3 & $\begin{array}{c}3836 \\
2452\end{array}$ & $\begin{array}{r}\text { (perch) } \\
\text { (rudd) }\end{array}$ \\
\hline 3. & Svyatoye, Kostyukovichy & 0.92 & 3.75 & $\begin{array}{c}60531 \\
15762 \\
14454 \\
17710\end{array}$ & $\begin{array}{r}\text { (perch) } \\
\text { (roach) } \\
\text { (rudd) } \\
\text { gudgeon) }\end{array}$ & 4.2 & $\begin{array}{r}14424 \\
3756 \\
3444 \\
4220\end{array}$ & $\begin{array}{r}\text { (perch) } \\
\text { (roach) } \\
\text { (rudd) } \\
\text { (gudgeon) }\end{array}$ \\
\hline 5. & Svyatskoye, Vetka & 4.8 & 14.5 & $\begin{array}{c}7098 \\
4463 \\
3370\end{array}$ & $\begin{array}{r}\text { (ruffe) } \\
\text { (perch) } \\
\text { (roach) }\end{array}$ & 4.9 & $\begin{array}{r}1691 \\
906 \\
684\end{array}$ & $\begin{array}{c}\text { (ruffe) } \\
\text { (perch) } \\
\text { (roach) }\end{array}$ \\
\hline 6. & Kolpino & 10.0 & 17.0 & $\begin{array}{r}527 \\
404\end{array}$ & $\begin{array}{l}\text { (perch) } \\
\text { (roach) }\end{array}$ & 1.2 & $\begin{array}{c}435 \\
334\end{array}$ & $\begin{array}{l}\text { (perch) } \\
\text { (roach) }\end{array}$ \\
\hline 7. & Svyatoye, Chechersk & 18.2 & 3.0 & $\begin{array}{c}169 \\
104 \\
88 \\
81\end{array}$ & $\begin{array}{r}\text { (perch) } \\
\text { (roach) } \\
\text { (ruffe) } \\
\text { (bream) }\end{array}$ & 0.99 & $\begin{array}{c}172 \\
106 \\
90 \\
82\end{array}$ & $\begin{array}{l}\text { (perch) } \\
\text { (roach) } \\
\text { (ruffe) } \\
\text { (bream) }\end{array}$ \\
\hline 8. & Stoyacheye & 8.4 & 5.0 & $\begin{array}{c}242 \\
194\end{array}$ & $\begin{array}{l}\text { (perch) } \\
\text { (roach) }\end{array}$ & 0.60 & $\begin{array}{c}403 \\
323\end{array}$ & $\begin{array}{l}\text { (perch) } \\
\text { (roach) }\end{array}$ \\
\hline 12. & Petrovshchina & 0.85 & 5.0 & $\begin{array}{r}1226 \\
917\end{array}$ & $\begin{array}{l}\text { (perch) } \\
\text { (roach) }\end{array}$ & 0.51 & $\begin{array}{c}2403 \\
1798\end{array}$ & $\begin{array}{l}\text { (perch) } \\
\text { (roach) }\end{array}$ \\
\hline 14. & Kozhanovskoe & 2.0 & 3.8 & $\begin{array}{r}24151 \\
8861\end{array}$ & $\begin{array}{l}\text { (perch) } \\
\text { (roach) }\end{array}$ & 9.2 & $\begin{array}{r}2625 \\
963\end{array}$ & $\begin{array}{l}\text { (perch) } \\
\text { (roach) }\end{array}$ \\
\hline 15. & Kiev Reservoir & 3.1 & 4.5 & $\begin{array}{c}8583 \\
236 \\
69 \\
100 \\
85\end{array}$ & $\begin{array}{r}\text { goldfish) } \\
\text { (perch) } \\
\text { (roach) } \\
\text { (rudd) }\end{array}$ & 0.18 & $\begin{array}{r}933 \\
1292 \\
377 \\
546 \\
464\end{array}$ & $\begin{array}{r}\text { (goldfish) } \\
\text { (perch) } \\
\text { (roach) } \\
\text { (rudd) }\end{array}$ \\
\hline 16. & Cooling Pond & 4.0 & 5.0 & $\begin{array}{r}85 \\
15360 \\
3700 \\
\end{array}$ & $\begin{array}{r}\text { (bream) } \\
\text { (perch) } \\
\text { (roach) }\end{array}$ & 4.0 & $\begin{array}{r}464 \\
3840 \\
925 \\
\end{array}$ & $\begin{array}{r}\text { (bream) } \\
\text { (perch) } \\
\text { (roach) }\end{array}$ \\
\hline
\end{tabular}




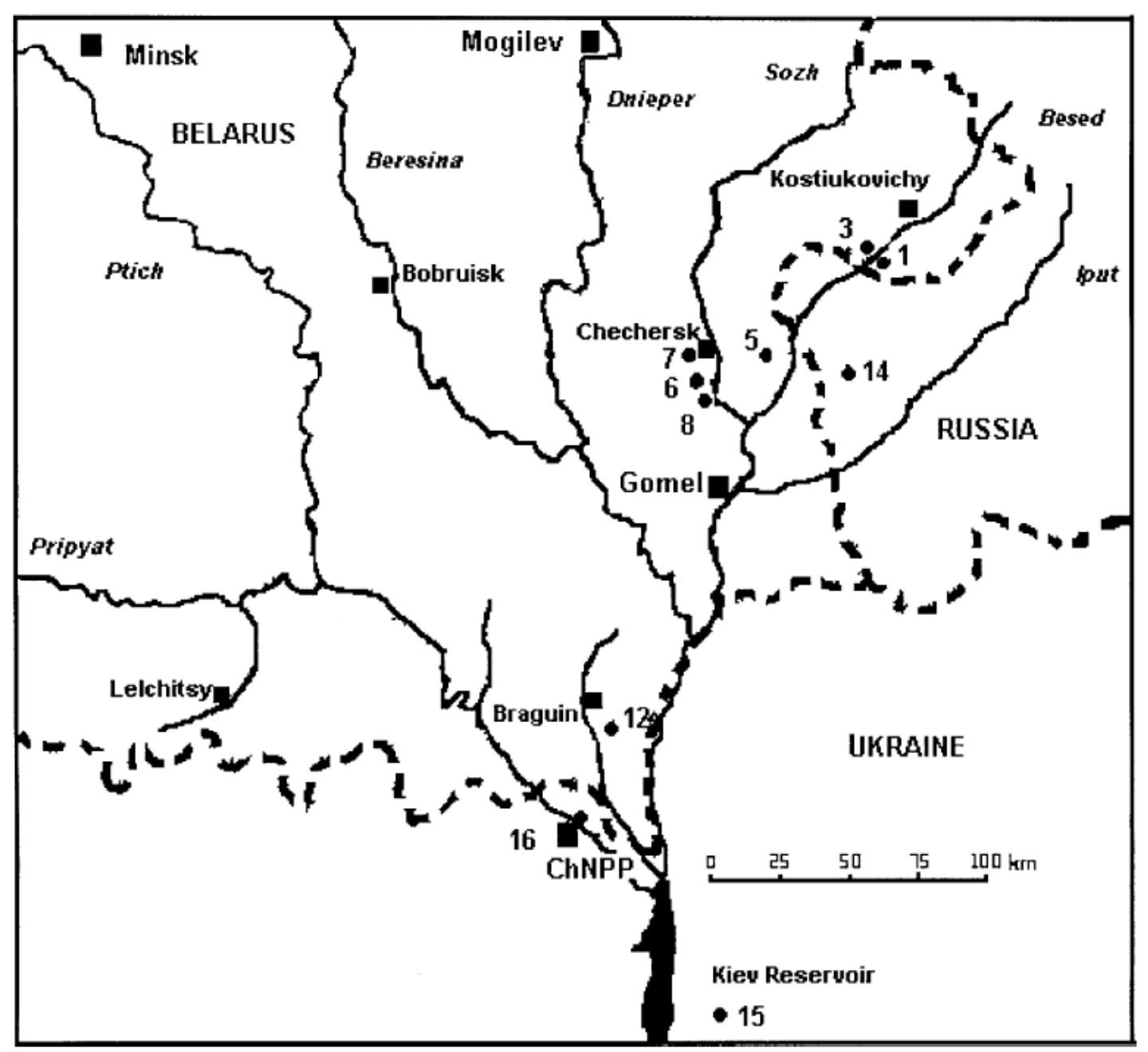

Fig. 1. Map of the study sites. Lakes are numbered as in Table 1. 
Perch

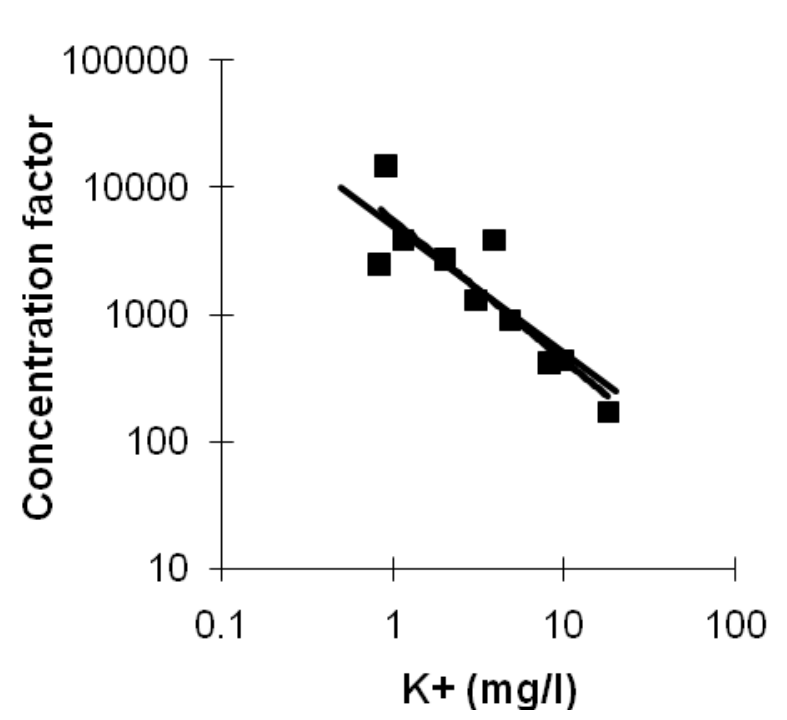

Roach

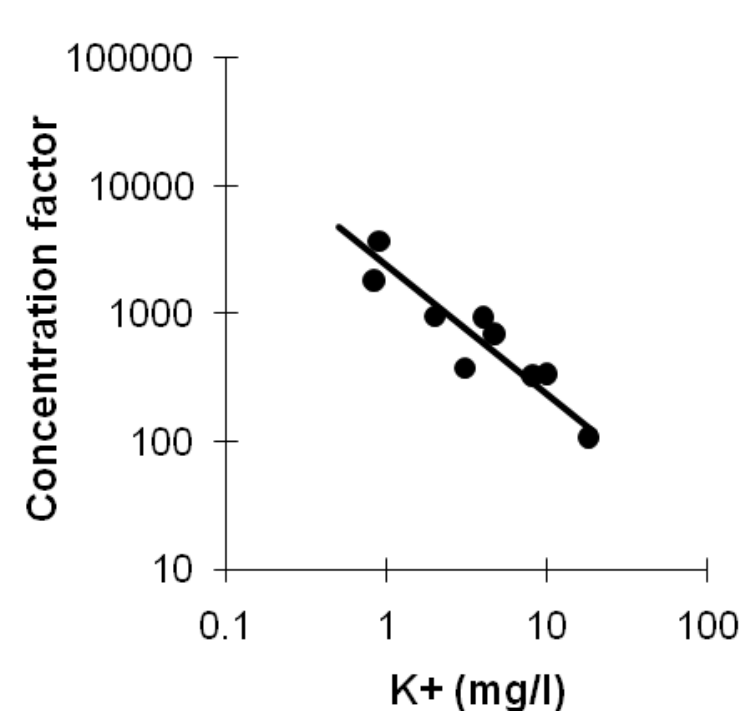

Other species

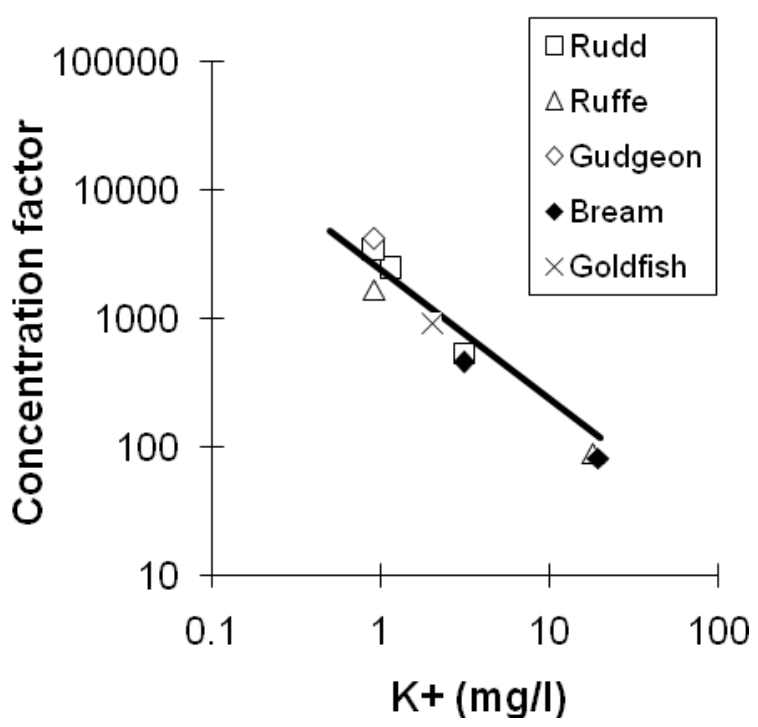

Figure 2. 
Perch

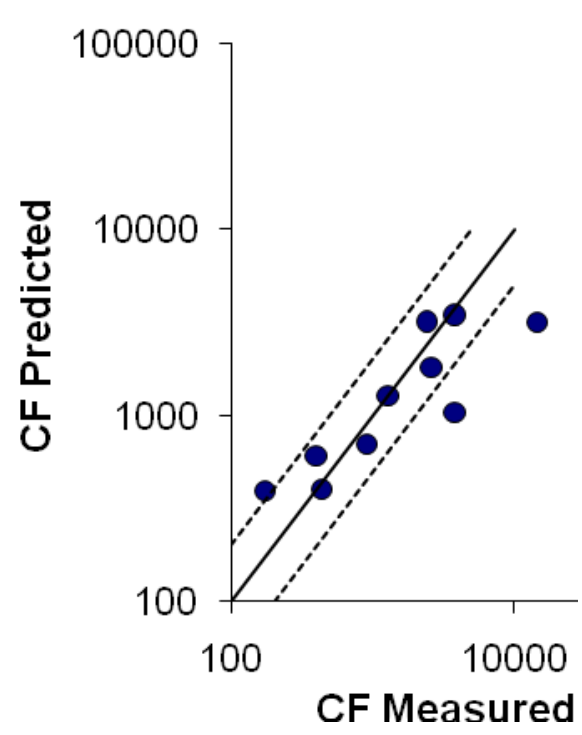

Roach

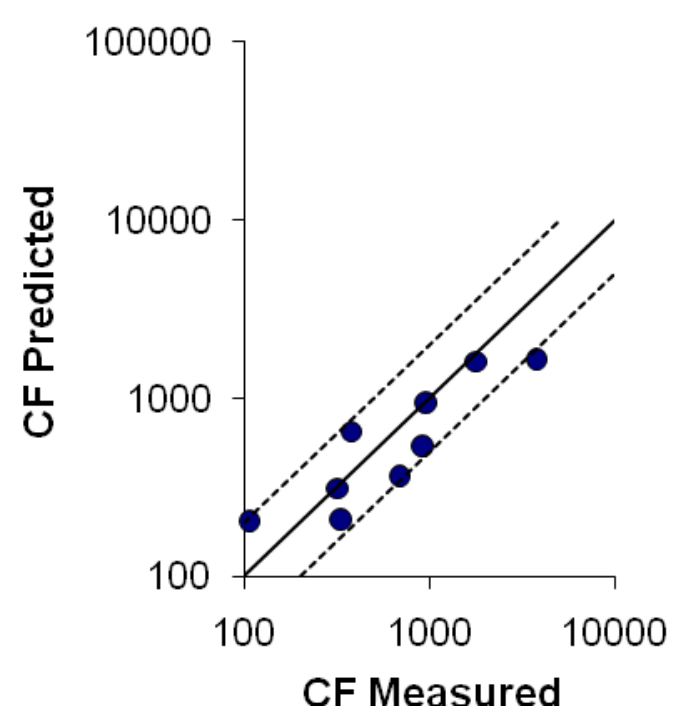

Other species

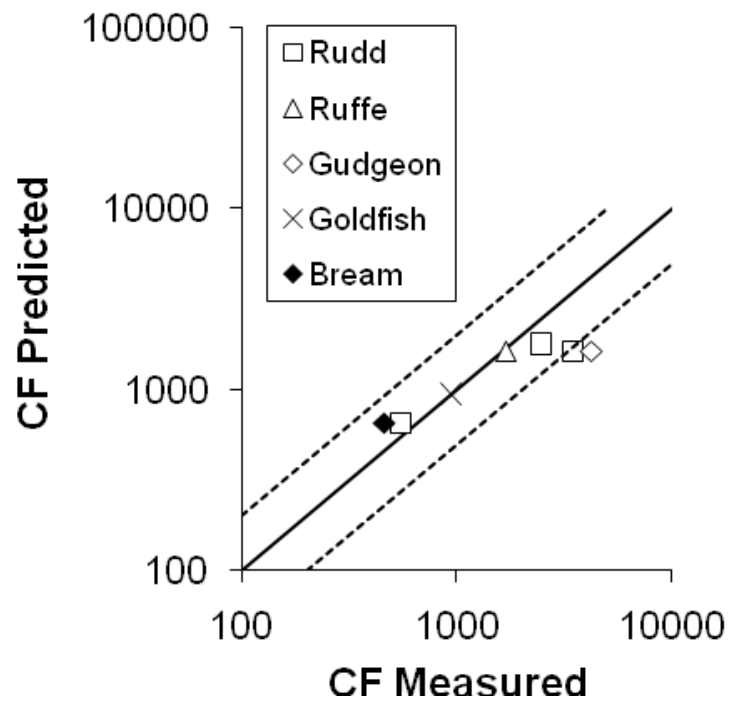

Figure 3. 